Article

\title{
Bioactivity of Selected Phenolic Acids and Hexane Extracts from Bougainvilla spectabilis and Citharexylum spinosum on the Growth of Pectobacterium carotovorum and Dickeya solani Bacteria: An Opportunity to Save the Environment
}

\author{
Nader A. Ashmawy $\left.{ }^{1}{ }^{(}\right)$, Said I. Behiry ${ }^{2}{ }^{(}$, , Asma A. Al-Huqail $^{3, *}$, Hayssam M. Ali $^{3}$ and \\ Mohamed Z. M. Salem 4,*(D) \\ 1 Plant Pathology Department, Faculty of Agriculture (El-Shatby), Alexandria University, Alexandria 21545, \\ Egypt; nader_pcr@yahoo.com \\ 2 Agricultural Botany Department, Faculty of Agriculture (Saba Basha), Alexandria University, \\ Alexandria 21531, Egypt; behiry_2006@yahoo.com \\ 3 Chair of Climate Change, Environmental Development and Vegetation Cover, Department of Botany and \\ Microbiology, College of Science, King Saud University, Riyadh 11451, Saudi Arabia; hayhassan@ksu.edu.sa \\ 4 Forestry and Wood Technology Department, Faculty of Agriculture (El-Shatby), Alexandria University, \\ Alexandria 21545, Egypt \\ * Correspondence: aalhuqail@ksu.edu.sa (A.A.A.-H.); zidan_forest@yahoo.com (M.Z.M.S.)
}

Received: 1 March 2020; Accepted: 15 April 2020; Published: 21 April 2020

\begin{abstract}
Phenolic acids and natural extracts, as ecofriendly environmental agents, can be used as bio bactericides against the growth of plant pathogenic bacteria. In this study, isolation trails from infected potato tubers and stems that showed soft rot symptoms in fields revealed two soft rot bacterial isolates and were initially identified through morphological, physiological, and pathogenicity tests. The molecular characterization of these isolates via PCR, based on the 16S rRNA region, was carried out by an analysis of the DNA sequence via BLAST and Genbank, and showed that the soft rot bacterial isolates belong to Pectobacterium carotovorum subsp. carotovorum (PCC1) and Dickeya solani (Ds1). The in vitro results of the tested phenolic acids against the cultured bacterial isolates proved that concentrations of 800,1600 , and $3200 \mu \mathrm{g} / \mathrm{mL}$ were the most effective. Ferulic acid was the potent suppressive phenolic acid tested against the Ds1 isolate, with an inhibition zone ranging from 6.00 to $25.75 \mathrm{~mm}$ at different concentrations $(25-3200 \mu \mathrm{g} / \mathrm{mL})$, but had no effect until reaching a concentration of $100 \mu \mathrm{g} / \mathrm{mL}$ in the PCC1 isolate, followed by tannic acid, which ranged from 7.00 to $25.50 \mathrm{~mm}$. On the other hand, tannic acid resulted in a significant decrease in the growth rate of the PCC1 isolate with a mean of $9.11 \mathrm{~mm}$. Chlorogenic acid was not as effective as the rest of the phenolic acids compared with the control. The $n$-hexane oily extract (HeOE) from Bougainvillea spectabilis bark showed the highest activity against PCC1 and Ds1, with inhibition zone values of 12 and $12.33 \mathrm{~mm}$, respectively, at a concentration of $4000 \mu \mathrm{g} / \mathrm{mL}$; while the HeOE from Citharexylum spinosum wood showed less activity. In the GC/MS analysis, nonanal, an oily liquid compound, was found ata percentage of $38.28 \%$, followed by cis-2-nonenal (9.75\%), which are the main compounds in B. spectabilis bark HeOE, and 2-undecenal $(22.39 \%)$, trans-2-decenal $(18.74 \%)$, and oleic acid $(10.85 \%)$ were found, which are the main compounds in C. spinosum wood HeOE. In conclusion, the phenolic acids and plant HeOEs seem to raise the resistance of potato plants, improving their defense mechanisms against soft rot bacterial pathogens.
\end{abstract}

Keywords: Pectobacterium; Dickeya; Bougainvilla; Citharexylum extract; ecofriendly environmental agents; phenolic acids 


\section{Introduction}

Potato (Solanum tubersum L.) is the world's fourth most consumed crop, with an estimated 374 million tons of production worldwide, obtained from nearly 17,623,660 hectares [1]. Potato is rated as one of Egypt's most significant vegetable crops, with a production total of 4,325,478 tons from around 163,939 hectares, making Egypt the second largest potato producer after Algeria. The main reasons for soft rot and blackleg disease in potatoes in warmer climates are Pectobacterium carotovorum subsp. carotovorum and P. atrosepticum [2,3], whereas, in Brazil and South Africa, the main causative agent for blackleg disease is P. carotovorum subsp. brasiliensis [4,5]. In early studies, Erwinia chrysanthemi was recognized as a causative agent of potato stem rot disease-recently reclassified as Dickeya spp. [6]. In Egypt, the main agents causing soft rot and blackleg disease are P. atrosepticum, P. carotovorum subsp. carotovorum [7-10], and Dickeya solani, P. carotovorum subsp. brasiliensis [4,11,12]. Potatoes with soft rot cause massive losses of over $40 \%$ to $80 \%$ as a result of weather factors $[13,14]$.

In the pathogenicity tests [15], 24 potato cultivars were tested for their susceptibility to soft rot caused by P. atrosepticum using a tuber slice test. The symptoms of soft rot on potato tuber, carrot, and sweet potato, as well as the fruits of eggplant and pepper, appear one to three days after inoculation with soft rot bacteria $[16,17]$. D. solani caused a greater loss of carrot tissue, higher than P. carotovorum subsp. carotovorum [18].

Chlorogenic, caffeic, and protocatechuic acids are the main phenolic acids in potato peels, while the mild phenolic acids are gallic, ferulic, and $p$-coumaric acids. The phenolic levels found in potato peels are significantly greater than in the potato flesh $[19,20]$. Phenolic acids are the first defense for potato tubers against Pectobacteria infection during wound healing, as they promote the inhibition of proteolytic activity or bactericide action [20-25].

Bougainvillea spectabilis (Bougainvillea), a popular woody shrub, grown in tropical and sub-tropical regions, has certain phytochemicals, such as saponins, quinones, flavonoids, triterpenoids, phenols, sterols, glycosides, furanoids, tannins, and small amounts of sugars [26-29]. B. spectabilis leaves contain d-pinitol (3-O-methylchiroinositol) [30]. Ethanolic and methanolic extracts from B. spectabilis leaves show a good antimicrobial effect against Gram-positive and -negative bacteria, and could replace the use of antibiotics [31].

Citharexylum spinosum (C. quadrangulare or C. fruticosum) belongs to the Verbenaceae family. Citharexylum species have shown good biological activities, such as antioxidant, nephroprotector, anti-inflammatory, gastroprotector, hypoglycemic, antipyretic, and antibacterial activities [32-35]. Carotenoids, iridoids, flavonoids, terpenoids, alkaloids, and saponines, which were isolated and identified from the extracts of Citharexylum species [32,36-38].

The objectives of the present study were to isolate and identify potato soft rot bacteria through classical and molecular tests, in order to determine the sensitivity of soft rot bacteria Pectobacterium carotovorum subsp. carotovorum (PCC1) and Dickeya solani (Ds1) toward some phenolic acids and plant extracts from B. spectabilis bark and C. spinosum wood.

\section{Materials and Methods}

\subsection{Isolation and Conventional Identification of the Soft Rot Bacteria}

Potato tubers showing soft rot and stems exhibiting blackleg symptoms were collected from different localities at El-Behira Governorate, Egypt (Table 1), and a bacterial pathogens isolation procedure was performed [39]. The morphological and biochemical characteristics tests were applied on the obtained soft rot bacterial isolates, and included cell shape, Gram staining, motility, anaerobic growth, growth at $36{ }^{\circ} \mathrm{C}$, gelatin liquefaction, indole formation, nitrate reduction, hydrolysis of starch, lipolytic activity, mucoid growth, $\mathrm{H}_{2} \mathrm{~S}$ production from cysteine, reducing substance from sucrose, acetoin production, urease production, oxidase, growth in $5 \% \mathrm{NaCl}$, and sensitivity to the antibiotic erythromycin [40]. The bacterial isolates were molecularly identified through 16S rRNA gene sequencing, according to Ashmawy et al. [16]. 


\subsection{Molecular Identification Throught the $16 S$ rRNA Gene}

After bacterial DNA isolation by CTAB method [16], a full length of the 16S rRNA gene (1550-bp) was amplified for the two bacterial isolates using primers-P0 as the forward (5'-GAAGAGTTTGATCCTGGCTCAG-3') and P6 as the reverse (5'-CTACGGCTACCTTGT GTTACGA-3'). PCR amplification was performed in a total volume of $50 \mu \mathrm{L}$, containing $25 \mu \mathrm{L}$ of master mix (enzymocis, korea), $2 \mu \mathrm{L}$ of each P0 or P6 primer (10 pmol) with final concentration $0.1-0.5 \mu \mathrm{M}$ of each primer, $2 \mu \mathrm{L}(50 \mathrm{ng} / \mu \mathrm{L})$ of bacterial genomic DNA, and molecular grade water was added until the volume reached $50 \mu \mathrm{L}$. The PCR reaction was carried out as follows: 1 cycle at $95^{\circ} \mathrm{C}(5 \mathrm{~min})$ for initial denaturation, and 35 cycles (denaturation for $45 \mathrm{~s}$ at $95{ }^{\circ} \mathrm{C}$, annealing for $60 \mathrm{~s}$ at $50^{\circ} \mathrm{C}$, and elongation for $120 \mathrm{~s}$ at $72{ }^{\circ} \mathrm{C}$ ) for the final extension, for $7 \mathrm{~min}$ at $72{ }^{\circ} \mathrm{C}$. PCR amplicons were visualized by an ultra-violet (UV) transilluminator [16].

Sequencing of $16 \mathrm{~S}$ rRNA Gene and BLASTn

The amplified amplicons of the 16S rRNA gene were purified and sequenced by a BigDye ${ }^{\circledR}$ Terminator v1.1 Cycle Sequencing Kit (ThermoFisher SCIENTIFIC, Waltham, MA, USA) and analyzed by 3130 Genetic Analyzer (Macrogen Co., Seoul, Korea). Alignment of the nucleotide sequences was performed with MSA CLUSTAL (Omega https://www.ebi.ac.uk/Tools/msa/) [16]. BLASTn was used for the nucleotide sequences comparisons on the GenBank website (https://blast.ncbi.nlm.nih.gov/Blast. cgi) $[41,42]$.

\subsection{Plant Material and Pathogenicity Test}

Potato tuber cultivar "Diamont" was obtained and examined for its ability to exhibit the soft rot symptoms, using the two bacterial isolates as cited by Manzira [14], and the disease severity index was estimated as PDI $=[(A-B) / A] * 100$. Here, PDI is the percentage of disease severity index, $\mathrm{A}$ is the tuber weight with rotting, and $B$ is the tuber weight without rotting [43].

\subsection{Source of Phenolic Acids, Extraction Method of Plant Parts Used, and GC/MS Analysis}

The phenolic compounds of caffeic, tannic, $p$-coumaric, protocatechuic, chlorogenic, and ferulic acid were purchased from Sigma-Aldrich (Merck). Samples of Bougainvillea spectabilis Willd. and Citharexylum spinosum L. plants were collected from Alexandria, Egypt, during September, 2018 and authenticated by Dr. Mohamed Z.M. Salem, Department of Forestry and Wood Technology, Alexandria University, Alexandria, Egypt (Voucher number Zidan0059, and Zidan0060, respectively). The extracts from B. spectabilis bark and C. spinosum wood were prepared by soaking $50 \mathrm{~g}$ of each part of the plant—in the form of powered material after air-drying—in n-hexane $(150 \mathrm{~mL})$ for $6 \mathrm{~h}$ under shaking, after which the extract was concentrated in a vacuum using a rotary evaporator.

\subsection{Influence of Some Phenolic Acids and Plant Extracts on Bacterial Growth}

The two bacterial isolates were tested against $0,25,50,100,200,400,800,1600$, and $3200 \mu \mathrm{g} / \mathrm{mL}$ concentrations of caffeic, tannic, $p$-coumaric, protocatechuic, chlorogenic, and ferulic acids using agar-well diffusion method in a nutrient agar (NA) medium. After $48 \mathrm{~h}$ of incubation, the inhibition zone $(\mathrm{mm})$ was measured, and the assays were replicated three times and the experiments conducted twice [44]. The extracts were prepared at concentrations of 125, 250, 500, 1000, 2000, and $4000 \mu \mathrm{g} / \mathrm{mL}$.

The chemical compositions of the n-hexane oily extracts (HeOEs) from B. spectabilis bark and $C$. spinosum wood were analyzed using a Focus GC-DSQ Mass Spectrometer (Thermo Scientific, Austin, TX, USA) with a direct capillary column of TG-5MS (30 $\mathrm{m} \times 0.25 \mathrm{~mm} \times 0.25 \mu \mathrm{m}$ film thickness). The temperature programs and column separation conditions can be found in previous work [45]. Identification of the compounds was done by a comparison of their retention times, as well as the MS reported from the WILEY 09 and NIST 11 mass spectral databases [46]. The values of the standard 
index (SI) and reverse standard index (RSI) were also reported in order to confirm that all of the spectra were appended to the library $[47,48]$.

\subsection{Statistical Analysis}

The data were analyzed statistically with a two-way analysis of variance (ANOVA) using SAS software (SAS Institute, NC, USA) [49]. The two factors that analyzed were phenolic and extracts, as well as their respective concentrations. The means of the treatments were compared with control treatment, according to the Duncan's Multiple Range Test at a 0.05 level of probability.

\section{Results}

\subsection{Isolation Trails of the Causal Bacterial Pathogens}

The isolation trails of the soft rot and blackleg symptoms (Figure 1) collected from the El-Nubaria and Wadi Elnatron regions, Egypt, revealed two bacterial isolates PCC1 and Ds1 which belonging to Pectobacterium and Dickeya genera, respectively (Table 1).

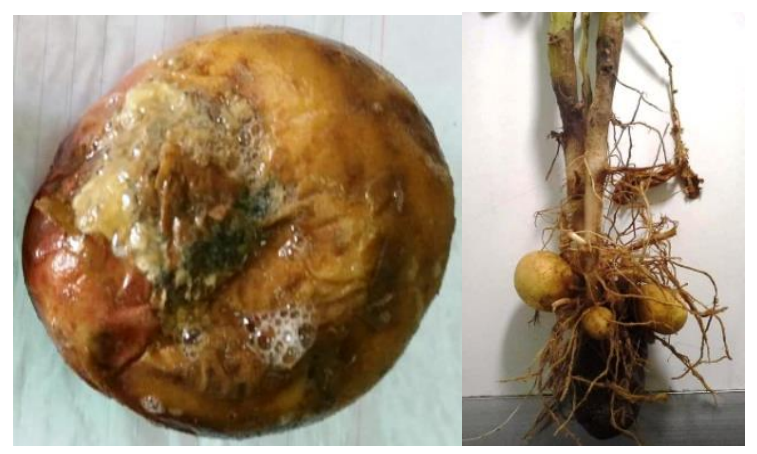

Figure 1. Natural infection of potato tubers with soft rot and blackleg symptoms: (left) Pectobacterium carotovorum subsp. carotovorum (PCC1) and (right) Dickeya solani (Ds1).

Table 1. Origin and disease index of soft rot and blackleg bacterial isolates.

\begin{tabular}{cccccc}
\hline $\begin{array}{c}\text { Bacterial } \\
\text { Genera }\end{array}$ & Isolates Code & Potato Part & Cultivar & Origin & $\begin{array}{c}\text { Disease Severity } \\
\text { Index } \pm \text { SD }\end{array}$ \\
\hline $\begin{array}{c}\text { Pectobacterium } \\
\text { Dickeya }\end{array}$ & PCC1 & Tuber & Roseta & $\begin{array}{c}\text { El-Nubaria, El-Behira, } \\
\text { Egypt } \\
\text { Wadi elnatron, }\end{array}$ & $86.04 \pm 0.97$ \\
Control & Ds1 & Stem & Hermes & El-Behira, Egypt & $71.62 \pm 0.53$ \\
& & & & & $0.00 \pm 0.00$ \\
\hline
\end{tabular}

\subsection{Phenotypic and Molecular Identification of the Soft Rot Bacteria}

Based on the morphological, biochemical, and physiological characteristics of the isolated soft rot bacteria, the bacterial isolates were identified as Pectobacterium carotovorum subsp. carotovorum (PCC1) and Dickeya solani (Ds1) (Table 2). The identification of the isolates PCC1 and Ds1 was confirmed using the $16 \mathrm{~S}$ rDNA sequences analysis, and was deposited in the GenBank database under accession numbers MN598002 and MN598003, respectively. 
Table 2. Morphological traits and physiological and biochemical reactions of Pectobacterium carotovorum subsp. carotovorum and Dickeya solani isolates.

\begin{tabular}{|c|c|c|}
\hline \multirow{2}{*}{ Characteristics } & \multicolumn{2}{|l|}{ Bacterial Isolates } \\
\hline & Pectobacterium carotovorum subsp. carotovorum & Dickeya solani \\
\hline Shape (rods) & + & + \\
\hline Gram staining & - & - \\
\hline Motility & + & + \\
\hline Anaerobic growth & + & + \\
\hline Potato soft rot & + & + \\
\hline Growth at $37^{\circ} \mathrm{C}$ & + & + \\
\hline Gelatin liquefaction & + & + \\
\hline Mucoid growth & + & + \\
\hline Kovac's oxidase & - & - \\
\hline $\mathrm{H} 2 \mathrm{~S}$ from cysteine & + & + \\
\hline Indole production & - & + \\
\hline R. substance from sucrose & - & - \\
\hline Urease production & - & - \\
\hline Growth in $5 \% \mathrm{NaCl}$ & + & - \\
\hline Sensitivity to erythromycin & - & + \\
\hline Phosphatase & - & + \\
\hline Malonate utilization & - & + \\
\hline Starch hydrolysis & + & + \\
\hline Glucose & a & $\mathrm{a}$ \\
\hline$\alpha$-methyl glucoside & - & - \\
\hline Maltose & - & $\mathrm{a}$ \\
\hline Lactose & a & $\mathrm{a}$ \\
\hline L-Arabinose & a & a \\
\hline Dulcitol & a & a \\
\hline Manitol & a & $\mathrm{a}$ \\
\hline Trehalose & a & - \\
\hline
\end{tabular}

Note: "+" = positive reaction; " -" = negative reaction; a = acid.

\subsection{Pathogenicity Tests}

The two tested bacterial isolates were pathogenic and produced soft rot symptoms on potato tubers. The PCC1 isolate showed a high disease index $(86.04 \%)$, while the disease index of the isolate Ds1 was $71.62 \%$ (Table 1 ).

\subsection{Influence of Some Phenolic Acids and Plant Oily Extracts on Growth of PCC1 and Ds1 Isolates}

The data presented in Table 3 show the highly significant effects of the tested phenolic acids/oily extracts and their concentrations against the growth of PCC1 and Ds1. Table 4 shows that the different concentrations of the tested phenolic acids or the n-hexane oily extracts (HeOEs) from Bougainvillea spectabilis bark and Citharexylum spinosum wood caused different degrees of growth inhibition on the PCC1 and Ds1 isolates. It is evident that ferulic acid was the most suppressive to Ds1 isolate growth, with an inhibition zone (IZ) that ranged from 6 to $25.75 \mathrm{~mm}$ but had no effect on the PCC1 isolate growth until reaching a concentration of $100 \mu \mathrm{g} / \mathrm{mL}$. On the other hand, tannic acid application decreased the growth rate of the PCC1 isolate with a mean of $9.11 \mathrm{~mm}$. Finally, chlorogenic acid was less effective than all of the other phenolic acids used compared with the control. Significant differences were found among all phenolics at concentrations of 400 and $800 \mu \mathrm{g} / \mathrm{mL}$. On the other hand, phenolic acid concentrations of 25 and $50 \mu \mathrm{g} / \mathrm{mL}$ had no noticeable effect on the two isolates, except for ferulic acid. Overall, the PCC1 isolate was more tolerant to all of the phenolic acids than the Ds1 isolate, and the applied concentrations of 800,1600 , and $3200 \mu \mathrm{g} / \mathrm{mL}$ were the most effective at inhibiting the two isolates. 
Table 3. Analysis of variance (ANOVA) for the significance effects of phenolic/extract, concentration, and their interaction against the growth of P. carotovorum and D. solani.

\begin{tabular}{cccccc}
\hline Source of Variance & DF & Type III SS & Mean Square & F Value & Pr $>$ F \\
\hline PCC1 & \multicolumn{5}{c}{} \\
\hline Concentrations (A) & 12 & 6604.123 & 550.343 & 1651.91 & $<0.0001$ \\
Phenolic/extract (B) & 6 & 269.392 & 44.898 & 134.77 & $<0.0001$ \\
A $\times$ B & 40 & 393.7006 & 9.842 & 29.54 & $<0.0001$ \\
\hline Ds1 & & & & \\
\hline A & 12 & 8346.289 & 695.524 & 5894.27 & $<0.0001$ \\
B & 6 & 1843.256 & 307.209 & 2603.47 & $<0.0001$ \\
A $\times$ B & 40 & 939.368 & 23.484 & 199.02 & $<0.0001$ \\
\hline
\end{tabular}

Table 4. Effect of phenolic acids/oily extracts at various concentrations against the growth of $P$. carotovorum subsp. carotovorum (PCC1) and D. solani (Ds1).

\begin{tabular}{|c|c|c|c|}
\hline \multirow{2}{*}{ Phenolic Acids/Extracts } & \multirow{2}{*}{ Concentrations $\mu \mathrm{g} / \mathrm{mL}$} & \multicolumn{2}{|c|}{ Inhibition Zone Diameter $(\mathrm{mm}) \pm \mathrm{SE}$} \\
\hline & & PCC1 & Ds1 \\
\hline \multirow{8}{*}{ Caffeic acid } & 25 & 0.00 & 0.00 \\
\hline & 50 & 0.00 & 0.00 \\
\hline & 100 & $7 \pm 0.00$ & 0.00 \\
\hline & 200 & $7 \pm 0.00$ & 0.00 \\
\hline & 400 & $8.5 \pm 0.28$ & $6 \pm 0.00$ \\
\hline & 800 & $13.75 \pm 0.14$ & $7.75 \pm 0.14$ \\
\hline & 1600 & $18 \pm 0.00$ & $18.75 \pm 0.14$ \\
\hline & 3200 & $20.7 \pm 0.46$ & $22.75 \pm 0.72$ \\
\hline \multirow{8}{*}{ Tannic acid } & 25 & 0.00 & 0.00 \\
\hline & 50 & 0.00 & 0.00 \\
\hline & 100 & $7 \pm 0.00$ & $7 \pm 0.00$ \\
\hline & 200 & $8.75 \pm 0.14$ & $11.75 \pm 0.14$ \\
\hline & 400 & $11.5 \pm 0.28$ & $15.25 \pm 0.14$ \\
\hline & 800 & $15.25 \pm 0.14$ & $17.25 \pm 0.14$ \\
\hline & 1600 & $17.25 \pm 0.14$ & $21.5 \pm 0.28$ \\
\hline & 3200 & $22.25 \pm 0.14$ & $25.5 \pm 0.00$ \\
\hline \multirow{8}{*}{$p$-Coumaric acid } & 25 & 0.00 & 0.00 \\
\hline & 50 & 0.00 & 0.00 \\
\hline & 100 & 0.00 & $8 \pm 0.00$ \\
\hline & 200 & 0.00 & $9 \pm 0.00$ \\
\hline & 400 & $7 \pm 0.00$ & $9 \pm 0.00$ \\
\hline & 800 & $10.25 \pm 0.14$ & $14 \pm 0.00$ \\
\hline & 1600 & $13 \pm 0.00$ & $17.5 \pm 0.28$ \\
\hline & 3200 & $18 \pm 0.28$ & $20.25 \pm 0.14$ \\
\hline \multirow{8}{*}{ Protocatechuic acid } & 25 & 0.00 & 0.00 \\
\hline & 50 & 0.00 & 0.00 \\
\hline & 100 & $7 \pm 0.00$ & 0.00 \\
\hline & 200 & $7 \pm 0.00$ & $6 \pm 0.00$ \\
\hline & 400 & $10.5 \pm 0.28$ & $8 \pm 0.00$ \\
\hline & 800 & $11.87 \pm 0.36$ & $8.75 \pm 0.14$ \\
\hline & 1600 & $12 \pm 0.00$ & $11 \pm 0.00$ \\
\hline & 3200 & $14.75 \pm 0.14$ & $14.5 \pm 0.28$ \\
\hline
\end{tabular}


Table 4. Cont.

\begin{tabular}{|c|c|c|c|}
\hline \multirow{2}{*}{ Phenolic Acids/Extracts } & \multirow{2}{*}{ Concentrations $\mu \mathrm{g} / \mathrm{mL}$} & \multicolumn{2}{|c|}{ Inhibition Zone Diameter $(\mathrm{mm}) \pm S E$} \\
\hline & & PCC1 & Ds1 \\
\hline \multirow{8}{*}{ Chlorogenic acid } & 25 & 0.00 & 0.00 \\
\hline & 50 & 0.00 & 0.00 \\
\hline & 100 & 0.00 & 0.00 \\
\hline & 200 & $6 \pm 0.00$ & $11.5 \pm 0.00$ \\
\hline & 400 & $10 \pm 0.00$ & $15.5 \pm 0.00$ \\
\hline & 800 & $13.5 \pm 0.28$ & $22 \pm 0.28$ \\
\hline & 1600 & $18.5 \pm 0.28$ & $25.5 \pm 0.00$ \\
\hline & 3200 & $19.25 \pm 1.01$ & $25.25 \pm 0.43$ \\
\hline \multirow{8}{*}{ Ferulic acid } & 25 & 0.00 & $6 \pm 0.00$ \\
\hline & 50 & 0.00 & $9 \pm 0.00$ \\
\hline & 100 & $6.5 \pm 0.28$ & $11.5 \pm 0.28$ \\
\hline & 200 & $7 \pm 0.00$ & $14.75 \pm 0.14$ \\
\hline & 400 & $8.5 \pm 0.00$ & $18.5 \pm 0.00$ \\
\hline & 800 & $12.25 \pm 0.14$ & $22.5 \pm 0.00$ \\
\hline & 1600 & $17.75 \pm 0.14$ & $24.25 \pm 0.14$ \\
\hline & 3200 & $21.5 \pm 0.57$ & $25.75 \pm 0.14$ \\
\hline \multirow{6}{*}{$\begin{array}{c}\text { Bougainvillea spectabilis } \\
\text { bark }\end{array}$} & 125 & $6.66 \pm 0.88$ & $6.83 \pm 0.16$ \\
\hline & 250 & $7.33 \pm 0.66$ & $7.16 \pm 0.16$ \\
\hline & 500 & $7.33 \pm 0.33$ & $9.33 \pm 0.46$ \\
\hline & 1000 & $9 \pm 0.57$ & $10 \pm 0.33$ \\
\hline & 2000 & $9.66 \pm 0.33$ & $11 \pm 0.22$ \\
\hline & 4000 & $12 \pm 0.57$ & $12.33 \pm 0.33$ \\
\hline \multirow{6}{*}{$\begin{array}{l}\text { Citharexylum spinosum } \\
\text { wood }\end{array}$} & 125 & $6.33 \pm 0.88$ & $6.16 \pm 0.44$ \\
\hline & 250 & $6.66 \pm 0.66$ & $6.5 \pm 0.28$ \\
\hline & 500 & $6.66 \pm 0.66$ & $7.5 \pm 0.28$ \\
\hline & 1000 & $7 \pm 0.57$ & $7.83 \pm 0.16$ \\
\hline & 2000 & $8.66 \pm 0.33$ & $8.33 \pm 0.33$ \\
\hline & 4000 & $10 \pm 0.57$ & $8.5 \pm 0.28$ \\
\hline Control & 0 & 0.00 & 0.00 \\
\hline$p$-value & & $* *$ & $* *$ \\
\hline
\end{tabular}

Additionally, from Table 4, the $n$-hexane oily extracts (HeOEs) from B. spectabilis bark and $C$. spinosum wood showed that with increasing the HeOE concentration, the IZ observed against the growth of PCC1 and Ds1was increased. The highest IZ $(12 \mathrm{~mm})$ against PCC1 was observed for $B$. spectabilis bark $\mathrm{HeOE}$ applied at a concentration of $4000 \mu \mathrm{g} / \mathrm{mL}$, followed by the same HeOE with an IZ of $9.66 \mathrm{~mm}$ at a concentration of $2000 \mu \mathrm{g} / \mathrm{mL}$. Furthermore, B. spectabilis bark HeOE at 4000, 2000, and $1000 \mu \mathrm{g} / \mathrm{mL}$ showed the highest IZs against the growth of Ds1, with values of $12.33,11$, and $10.33 \mathrm{~mm}$, respectively. Furthermore, C. spinosum HeOE showed an IZ value of $10 \mathrm{~mm}$ against the growth of PCC1 at $4000 \mu \mathrm{g} / \mathrm{mL}$ level of concentration. Overall, the phenolic acids showed the highest activity against the growth of both of the bacteria, compared with the HeOEs.

\subsection{Chemical Constituents of B. spectabilis Bark and C. spinosum Wood Oily Extracts}

Table 5 presents the chemical composition of the B. spectabilis bark HeOE. The main dominant compounds were nonanal $(38.28 \%)$, cis-2-nonenal $(9.75 \%)$, octanal $(8.16 \%), \beta$-sitosterol $(7.8 \%)$, 3-hydroxy-dodecanoic acid (6.9\%), heptanal (4.03\%), 8-oxabicyclo[5.1.0]octane (3.50\%), (E)-2-octen-1-al (2.68\%), 1-decene (1.92\%), (E)-2-decen-1-ol (1.84\%), 9-oxabicyclo[6.1.0]nonan-4-ol (1.39\%), and 1-chlorohexane $(1.18 \%)$. 
Table 5. Phytochemicals of $B$. spectabilis bark HeOE by GC/MS.

\begin{tabular}{cccc}
\hline Compound & Value in the Extract (\%) & SI $^{\mathbf{1}}$ & RSI $^{\mathbf{2}}$ \\
\hline Hex-2-ulosonic acid & 0.49 & 659 & 718 \\
1-Chlorohexane & 1.18 & 675 & 683 \\
5-heptyldihydro-2(3H)-furanone & 0.57 & 710 & 725 \\
2-Ethylpentane & 0.53 & 707 & 873 \\
Octane & 0.54 & 816 & 877 \\
Hexanal & 0.72 & 773 & 808 \\
2-Hexyl-cyclopropaneacetic acid & 0.33 & 749 & 789 \\
9-Oxabicyclo[6.1.0]nonan-4-ol & 1.39 & 665 & 674 \\
2-Undecanol & 0.72 & 648 & 847 \\
1-Hydroperoxyhexane & 0.48 & 646 & 745 \\
Heptanal & 4.03 & 763 & 817 \\
3-sitosterol & 7.8 & 838 & 951 \\
(E)-2-Decen-1-ol & 1.84 & 681 & 686 \\
8-Oxabicyclo[5.1.0]octane & 3.50 & 692 & 745 \\
Isopinocarveol & 0.93 & 651 & 686 \\
Octanal & 8.16 & 814 & 832 \\
8,11-Octadecadiynoic acid methyl ester & 0.78 & 684 & 691 \\
5-Isopropenyl-2-methyl-2-cyclohexen-1-ol & 0.40 & 675 & 684 \\
(E)-2-Octen-1-al & 2.68 & 770 & 823 \\
trans-Pinocarveol & 0.27 & 700 & 758 \\
(Z)-2-Tridecenal & 0.58 & 723 & 792 \\
2-Hexyl-cyclopropaneacetic acid & 0.20 & 710 & 754 \\
1-Decene & 1.92 & 737 & 741 \\
Nonanal (Pelargonaldehyde) & 38.28 & 896 & 912 \\
Tetradecan-1-ol & 0.30 & 691 & 693 \\
2-Phenylbutanal & 0.98 & 680 & 688 \\
cis-2-Nonenal & 0.94 & 676 & 680 \\
3-Hydroxy-dodecanoic acid & 9.75 & 792 & 885 \\
13,16-Octadecadiynoic acid methyl ester & 6.9 & 736 & 737 \\
\hline 1: SI standard & & &
\end{tabular}

${ }^{1}$ : SI $=$ standard index ${ }^{2}$ : RSI $=$ reverse standard index.

The chemical compositions of the HeOE from C. spinosum wood are shown in Table 6 . The abundant chemical constituents were 2-undecenal (22.39\%), trans-2-decenal (18.74\%), oleic acid (10.85\%), nonanal (9.75\%), 2-methylenecholestan-3-ol (6.01\%), (Z)-2-tridecenal (4.03\%), Z-(13,14-epoxy)tetradec-11-en-1-ol acetate (3.58\%), 3-hydroxy-dodecanoic acid (3.34\%), 9-hexadecenoic acid (2.3\%), 1-dodecene (1.96\%), (E)-2-nonenal (1.78\%), octanal (1.72\%), and 12,15-octadecadiynoic acid methyl ester $(1.7 \%)$.

Table 6. Phytochemicals of C. spinosum wood HeOE byGC/MS.

\begin{tabular}{cccc}
\hline Compound & Value in the Extract (\%) & SI $^{\mathbf{1}}$ & RSI $^{\mathbf{2}}$ \\
\hline 2,7-dimethyl-1-Octanol & 0.32 & 721 & 787 \\
1-Dodecene & 1.96 & 763 & 763 \\
2-Undecanol & 1.39 & 848 & 172 \\
Octanal & 1.72 & 809 & 838 \\
(Z)-2-Tridecenal & 4.03 & 778 & 838 \\
Nonanal & 9.75 & 889 & 914 \\
Hexadecanoic acid phenylmethyl ester & 0.92 & 706 & 720 \\
(E)-2-Nonenal & 1.78 & 786 & 902 \\
3-Hydroxy-dodecanoic acid & 3.34 & 821 & 821 \\
trans-2-Decenal & 18.74 & 981 & 799 \\
(E)-Hydroxydodecanoic acid & 0.77 & 797 & 803 \\
2-methylenecholestan-3-ol & 1.48 & 795 & 868 \\
2-Undecenal & 6.01 & 749 & 926 \\
1,2-15,16-Diepoxyhexadecane & 22.39 & 899 & 807 \\
9-Hexadecenoic acid & 1.21 & 798 & 830 \\
1-acetyl-16-methoxy-aspidospermidin-17-ol & 1.04 & 800 & 811 \\
12,15-Octadecadiynoic acid methyl ester & 2.3 & 806 & 793
\end{tabular}

${ }^{1}: \mathrm{SI}=$ standard $_{\text {index }}{ }^{2}: \mathrm{RSI}=$ reverse standard index. 


\section{Discussion}

Soft rot disease causes huge economic losses, estimated to be between $40 \%$ to $80 \%$ depending on climatic conditions, and Pectobacterium carotovorum subsp. carotovorum (PCC1) and Dickeya solani (Ds1) are the causal agents of soft rot disease in potato tubers in stores and in the field, where the early decay of mother tubers or seed tuber pieces may occur [13,14,50-52]. The pathological behavior of the isolated bacterial cultures, as well as their cultural, morphological, and physiological characters conform to those known for all soft rot bacteria. On the basis of the obtained data, we could identify these isolates as PCC1 and Ds1, in the same way as many other researchers have in previous works $[4,11,12,40,53-55]$.

Nowadays, the major objective of modern Egyptian agriculture is to offer a strategy that would lead to minimizing the use of chemical pesticides, at the same time increasing the economic yield of crops. Therefore, much attention has been given to hinder the severity and spread of plant diseases, especially bacterial plant pathogens, by using all possible non-polluting methods of plant disease control. The objective of this research was to describe the tolerance of isolates PCC1 and Ds1 to phenolic acids. The findings in the present work showed that ferulic and tannic acids had a substantial inhibitory impact on the growth of Ds1 and PCC1 isolates. A mixture of caffeic and chlorogenic acids could prevent bacterial soft rot infection from occurring, and the major phenolic acids detected in the tuber peels that had soft rot antimicrobial effects were chlorogenic, caffeic, and ferulic acids [21,22].

Tannic acid inhibited the growth of certain bacterial strains [56], while tannic and gallic acids inhibited the growth and protease or pectatelyase enzyme activities of the soft rot isolate D. solani [23]. A more pronounced antimicrobial impact at different concentrations was found for tannic acid. The size difference and percentage of $\mathrm{oH}^{-}$groups between ferulic and tannic acids can explain this varied response against soft rot bacterial pathogens [57]. Both phenolic acids can affect pathogen growth by contact with the produced protease and pectate lyase enzymes, the effective mechanism could be described as protein inhibitors by modifying their stability and losing cellular permeability, or by reducing the substrate availability or chelating the metal co-factor, as the tannic acid can fix the iron metal [58-63]. In this study, both isolates (PCC1 and Ds1) were growth inhibited by the examined polyphenols, and we suggest that the mode of action could interact and inactivate the enzyme active sites, which leads to precipitating the enzymatic proteins. This is in agreement with several authors who have talked about the mechanisms of tannic acid, polyphenol compounds, and their significant biological impacts, for example as bactericidal, antiviral, or fungal repressors [64,65].

Fatty acid and fatty alcohols, such as n-octacos-9-enoic acid and $n$-hentriacontanol, were isolated from Bougainvillea spectabilis roots [66]. Butyl formate, butyl acetate, methyl 2-methylbutanoate, methyl hexadecanoate, ethyl hexadecanoate, hexanal, heptanal, ethyl 3-hydroxy-hexanoate, and methyl linolenate were isolated from leaves and branches [67]. (Z)-2-hexenal, linaool, 2-heptadecanone, toluene, $O$-xylene, 2-furfural, terpinolene, terpinen-4-ol, and methyl salicylate were identified in the leaves and branches of B. spectabilis [67]. Compounds of bougainvinone A-M were isolated from stem bark of B. spectabilis [26], also, quercitrin as a flavonoid compound has been isolated from the stem bark [28]. Different solvent extractions, such as methanol, ethanol, water, chloroform, and ethyl acetate, were used to extract the chemical compounds from different parts of $B$. spectabilis, and have observed a good antibacterial activity [68-70]. B. spectabilis might be considered as a potential source of metabolites, which could be developed as precursors for antimicrobial and antioxidant drugs [71].

Citharexylum spinosum has been reported to have some biological isolated compounds, such as 5-deoxy pulchelloside, 8-epiloganin, iridoid glucoside, lamiidoside, duranterectoside $C$, and the lignan glucoside [36,72]. Flower essential oil and extracts exhibited antibacterial and antioxidant activities [33,73,74]. At $8 \mu \mathrm{g} / \mathrm{mL}$ of concentrated methanol extract of $C$. spinosum wood, there was a potent inhibition against the growth of $P$. variotii seen [75]. The B. spectabilis extract was more effective than $C$. spinosum extract, and this may be because it contains aldehydes and huge amounts of volatile compounds, such as nonanal, which was found in the phytochemical analysis at a percentage of $38.28 \%$. The biological activities of nonanal have only been reported in a few publications, as it significantly inhibits the mycelia growth of P. cyclopium [76]. 
The inhibitory effect of $B$. spectabilis extract could correlate with the concentration of nonanal versa C. spinosum wood extracts, and these results are the same as other reports [77-79]. Inhibition against $A$. niger and P. selerotigenum growth was found with minimum inhibitory concentration (MIC) values of $250 \mu \mathrm{g} / \mathrm{mL}$ and $500 \mu \mathrm{g} / \mathrm{mL}$, respectively [76]. Chloroform leaf extract from C. spinosum showed a weak activity against $P$. carotovorum subsp. carotovorum, P. atrosepticum and D. solani, [80]. The stem-bark ethyl acetate extract of $C$. spinosum showed the presence of vanillic acid [38]. $\rho$-coumaric acid, salicylic acid, and hispidulin were identified in the Citharexylum genus to have a good antimicrobial activity [81]. The $n$-butanol extract and essential oil (EO) of the cones of Pinus halepensis had a great antibacterial effect against the soft rot bacteria D. solani and P. atrosepticum [82].

Nonanal, the main oily compound found B. spectabilis bark HeOE, a saturated fatty aldehyde, arises from a reduction in the carboxy group of nonanoic acid. The unexplainable phenomena were not noted in nonanal alone, suggesting that aldehyde hydrocarbons are much more effective in managing postharvest diseases than alcohols and olefine [83]. Octanal and nonanal showed medium activity among the aldehyde constituents [84].

The prospective concepts underlying the antimicrobial activity of aldehyde and terpenes are not fully realized, but a number of possible strategies have been proposed. It is recognized that Gram-negative bacteria are more resistant than Gram-positive bacteria to EOs components $[85,86]$. Unsaturated aldehydes such as (E)-2-hexenal, (E)-2-octenal, and (E)-2-nonenalhave been shown a noticeable activity against several fungal and bacterial isolates $[87,88]$. Thus, these aldehydes might be good compounds for playing a reserving role against human diseases caused by bacteria or as food preservatives, or might be a good alternative to other highly toxic disinfectants for hospital equipment. Recently, Pinus halepensis branch HeOE showed the presence of 2-undecenal, (Z)-2-decenal, nonanal, (2E)-2-decenal, and decadienal as main compounds, with a good antifungal activity against $B$. oryzae and F. oxysporum [89].

In the present study, in vitro antibacterial activity has encouraged us to assume that the potential antibacterial activity of nonanal, an essential compounds from hydrophobic oil, against P. carotovorum subsp. carotovorum, and D. solani could be closely correlated with the physiology of the membrane [90-92]. In addition, fatty acid methyl esters or aldehydes are able to penetrate the hydrophobic regions of the membranes, and the carboxyl groups pass through the cell membrane, causing the lowering of the internal $\mathrm{pH}$ and denaturing of proteins inside the cell [93-96].

The most bioactive molecules found naturally in plants are phenolics, such as tannins and lignans. The hydroxycinnamic (a) and the hydroxybenzoic (b) acids, are two main groups of phenolics; (a) group contains caffeine, ferulic and $p$-coumaric acids, but the (b) group contains gallic, protocatechic acids $[97,98]$. $p$-Coumaric acid is the stepping stone in synthesis process of caffeic, chlorogenic and ferulic acids, and these phenolics lead to have an antimicrobial and antiviral effects in different mode of actions as it could kill the fungal and bacterial cells by breakdowns and ruptures the plasma membrane [99-103]. In another study, the cinnamic acid proved to be effective in suppressing the virulent species of Pectobacterium spp. by blocks the quorum sensing molecules [22,104]. Several studies documented the strong antibacterial activity of the commercial form of caffeic, chlorogenic, and p-coumaric acids against multi bacterial isolates such as E. coli, Pseudomonas aeruginosa, Stenotrophomonas maltophilia and Salmonella typhimurium, with a minimum inhibitory concentration (MIC) values ranging from 8-1000 $\mu \mathrm{g} / \mathrm{mL}$ [105-108]. While Wang et al. [109], confirmed the broad spectrum of antibacterial activity of the ferulic acid sourced from Halimodendron halodendron (Pall.) plant material towards the plant bacterial strains Agrobacterium tumefaciens, Pseudomonas syringae pv. lachrymans, Xanthomonas campestris pv. vesicatoria [109].

\section{Conclusions}

In the present study, isolates from Pectobacterium carorovorum subsp. carotovorum and Dickeya solani were conventionally and molecularly identified, and were proven to be pathogenic and cause potato soft rot. Oily extracts of Bougainvillea spectabilis bark (Ca. 4000, 2000, and $1000 \mu \mathrm{g} / \mathrm{mL}$ ) at phenolic acid 
concentrations of 800,1600 , and $3200 \mu \mathrm{g} / \mathrm{mL}$ were the most effective against bacterial isolate growth. Our present study suggests that phenolics and plant extracts might be used as bactericides to fight against soft rot bacterial diseases.

Author Contributions: N.A.A., S.I.B., and M.Z.M.S. designed the experiments, wrote parts of the manuscript, conducted laboratory analyses, and interpreted the results; A.A.A.-H. and H.M.A. contributed reagents/materials/analytical tools, and revised and amended the article for technical merits. All authors have read and agreed to the published version of the manuscript.

Funding: This research was funded by the Deanship of Scientific Research, King Saud University through the Vice Deanship of Scientific Research Chairs.

Acknowledgments: The authors are grateful to the Deanship of Scientific Research, King Saud University, for funding through the Vice Deanship of Scientific Research Chairs.

Conflicts of Interest: The authors declare no conflict of interest.

\section{References}

1. FAO STAT. Agriculture Data Source. 2017. Available online: http://faostat.fao.org/default.aspx (accessed on 17 May 2017).

2. Avrova, A.O.; Hyman, L.J.; Toth, R.L.; Toth, I.K. Application of amplified fragment length polymorphism fingerprinting for taxonomy and identification of the soft rot bacteria Erwinia carotovora and Erwinia solani. App. Environ. Microbiol. 2002, 68, 1499-1508. [CrossRef] [PubMed]

3. Pérombelon, M.C.M. Potato diseases caused by soft rot erwinias: An overview of pathogenesis. Plant Pathol. 2002, 51, 1-12. [CrossRef]

4. Duarte, V.; De Boer, S.H.; Ward, L.J.; De Oliveira, A.M.R. Characterization of atypical Erwinia carotovora strains causing blackleg of potato in Brazil. J. App. Microbiol. 2004, 96, 535-545. [CrossRef] [PubMed]

5. Van der Merwe, J.J.; Coutinho, T.A.; Korsten, L.; van der Waals, J.E. Pectobacterium carotovorum subsp. brasiliensis causing blackleg on potatoes in South Africa. Eur. J. Plant Pathol. 2010, 126, 175-185. [CrossRef]

6. Zhang, Y.; Fan, Q.; Loria, R. A re-evaluation of the taxonomy of phytopathogenic genera Dickeya and Pectobacterium using whole-genome sequencing data. Syst. Appl. Microbiol. 2016, 39, 252-259. [CrossRef] [PubMed]

7. Ashmawy, N.A.; Behiry, S.I.; Ali, H.M.; Salem, M.Z.M. Evaluation of Tecomastans and Callistemon viminalis extracts against Potato soft rot bacteria in vitro. J. Pure Appl. Microbiol. 2014, 8, 667-673.

8. Behiry, S.I.; Okla, M.K.; Alamri, S.A.; EL-Hefny, M.; Salem, M.Z.M.; Alaraidh, I.A.; Ali, H.M.; Al-Ghtani, S.M.; Monroy, J.C.; Salem, A.Z.M. Antifungal and antibacterial activities of Musa paradisiaca L. peel extract: HPLC analysis of phenolic and flavonoid contents. Processes 2019, 7, 215. [CrossRef]

9. Okla, M.K.; Alamri, S.A.; Salem, M.Z.M.; Ali, H.M.; Behiry, S.I.; Nasser, R.A.; Soufan, W. Yield, Phytochemical Constituents, and Antibacterial Activity of Essential Oils from the Leaves/Twigs, Branches, Branch Wood, and Branch Bark of Sour Orange (Citrus aurantium L.). Processes 2019, 7, 363. [CrossRef]

10. Al-Huqail, A.A.; Behiry, S.I.; Salem, M.Z.M.; Ali, H.M.; Siddiqui, M.H.; Salem, A.Z.M. Antifungal, Antibacterial, and Antioxidant Activities of Acacia Saligna (Labill.) H. L. Wendl. Flower Extract: HPLC Analysis of Phenolic and Flavonoid Compounds. Molecules 2019, 24, 700. [CrossRef]

11. Laurila, J.; Ahola, V.; Lehtinen, A.; Joutsjoki, T.; Hannukkala, A.; Rahkonen, A.; Pirhonen, M. Characterization of Dickeya strains isolated from potato and river water samples in Finland. Eur. J. Plant Pathol. 2008, 122, 213-225. [CrossRef]

12. Cating, R.A.; Palmateer, A.J. First report of a bacterial soft rot on Tolumnia Orchids caused by a Dickeya sp. in the United States. Plant Dis. 2009, 93, 1354. [CrossRef] [PubMed]

13. Ngadze, E.; Icishahayo, D. Survey: To assess the distribution and impact of potato blackleg and soft rot diseases in Zimbabwe. IOSR J. Agric. Vet. Sci. 2014, 7, 126-132. [CrossRef]

14. Ngadze, E.; Brady, C.L.; Coutinho, T.A.; van der Waals, J.E. Pectinolytic bacteria associated with potato soft rot and blackleg in South Africa and Zimbabwe. Eur. J. Plant Pathol. 2012, 134, 533-549. [CrossRef]

15. Lapwood, D.H.; Read, P.J. A simplified slice method for assessing tuber susceptibility of potato cultivars to Erwinia carotovora subsp. atroseptica. Plant Pathol. 1985, 34, 284-286. [CrossRef] 
16. Ashmawy, N.A.; El-Bebany, A.F.; Shams, A.H.; Shoeib, A.A. Identification and differentiation of soft rot and blackleg bacteria from potato using nested and multiplex PCR. J. Plant Dis Prot. 2020, 127, 141-153. [CrossRef]

17. Saleh, O.I.; Huang, J.S. Bacterial soft rot disease of tomato fruits in Florida USA: Identification, response of some American and Egyptian cultivars of solanaceous plants and chemical control. Assiut J. Agric. Sci. 1997, 28, 11-26.

18. Farrar, J.J.; Nunez, J.J.; Davis, R.M. Influence of soil saturation and temperature on Erwinia solani soft rot of carrot. Plant Dis. 2000, 84, 665-668. [CrossRef]

19. Mohdaly, A.; Sarhan, M.; Mahmoud, A.; Ramadan, M.; Smetanska, I. Antioxidant efficacy of potato peels and sugar beet pulp extracts in vegetable oils protection. Food Chem. 2010, 123, 1019-1026. [CrossRef]

20. Deusser, H.; Guignard, C.; Hoffmann, L.; Evers, D. Polyphenol and glycoalkaloid contents in potato cultivars grown in Luxembourg. Food Chem. 2012, 135, 2814-2824. [CrossRef]

21. Kumar, A.; Pundhir, V.S.; Gupta, K.C. The role of phenols in potato tuber resistance against soft rot by Erwinia carotovora ssp. carotovora. Potato Res. 1991, 34, 9-16. [CrossRef]

22. Joshi, J.R.; Burdman, S.; Lipsky, A.; Yariv, S.; Yedidia, I. Plant phenolic acids affect the virulence of Pectobacterium aroidearum and P. carotovorum ssp. brasiliense via quorum sensing regulation. Mol. Plant Pathol. 2015, 17, 487-500. [CrossRef]

23. Yahiaoui-Zaidi, R.; Zaidi, F.; Ait Bessai, A. Influence of gallic and tannic acids on enzymatic activity and growth of Pectobacterium solani (Dickeya solanibv. solani). Afr. J. Biotechnol. 2008, 7, 482-486.

24. Lagonenko, L.; Lagonenko, A.; Evtushenkov, A. Impact of salicylic acid on biofilm formation by plant pathogenic bacteria. J. Biol. Earth Sci. 2013, 3, B176-B181.

25. Czajkowski, R.; van der Wolf, J.; Krolicka, A.; Ozymko, Z.; Narajczyk, M.; Kaczynska, N.; Lojkowska, E. Salicylic acid can reduce infection symptoms caused by Dickeya solani in tissue culture grown potato (Solanum tuberosum L.) plants. Eur. J. Plant Pathol. 2015, 141, 545-558. [CrossRef]

26. Do, L.T.M.; Aree, T.; Siripong, P.; Pham, T.N.K.; Nguyen, P.K.P.; Tip-Pyang, S. Bougainvinones A-H, peltogynoids from the stem bark of purple Bougainvillea spectabilis and their cytotoxic activity. J. Nat. Prod. 2016, 79, 939-945. [CrossRef] [PubMed]

27. Do, L.T.; Aree, T.; Siripong, P.; Vo, N.T.; Nguyen, T.T.; Nguyen, P.K.; Tip-pyang, S. Cytotoxic flavones from the stem bark of Bougainvillea spectabilis willd. Planta Medica 2018, 84, 129-134. [CrossRef]

28. Jawla, S.; Kumar, Y.; Khan, M.S.Y. Isolation of antidiabetic principle from Bougainvillea spectabilis willd (Nyctaginaceae) stem bark. Trop. J. Pharma. Res. 2013, 12, 761-765. [CrossRef]

29. Abarca-Vargas, R.; Petricevich, V.L. Bougainvillea Genus: A Review on Phytochemistry, Pharmacology, and Toxicology. Based Complement. Alternat. Med. 2018, 2018, 9070927. [CrossRef]

30. Narayanan, C.R.; Joshi, D.D.; Mujumdar, A.M.; Dhekne, V.V. Pinitol, a new antidiabetic compound from the leaves of Bougainvillea spectabilis. Curr. Sci. 1987, 56, 139-141.

31. Fawad, S.A.; Khalid, N.; Asghar, W.; Suleria, H.A.R. In vitro comparative study of Bougainvillea spectabilis "stand" leaves and Bougainvillea variegata leaves in terms of phytochemicals and antimicrobial activity. Chin. J. Nat. Med. 2012, 10, 441-447. [CrossRef]

32. Khan, M.R.; Siddique, F. Antioxidant effects of Citharexylum spinosum in $\mathrm{CCl}_{4}$ induced nephrotoxicity in rat. Exp. Toxicol. Pathol. 2012, 64, 349-355. [CrossRef]

33. Mar, A.; Pripdeevech, P. Chemical composition and antibacterial activity of essential oil and extracts of Citharexylum spinosum flowers from Thailand. Nat. Prod. Commun. 2014, 9, 707-710. [CrossRef] [PubMed]

34. Hamed, A.N.E.; Muhammad, M.H.H.; Khalil, H.E.; Kamel, M.S. Biological Studies of Citharexylum quadrangulare Jacq. Family Verbenaceae. Assiut Univ. 9th International Pharmaceutical Sciences Conference 2014. Available online: https://www.researchgate.net/publication/274376180_Assiut_Citharexylum_Bio|T1\ textgreater\{\}Abstract_form (accessed on 12 March 2014).

35. Mohammed, M.H.H.; Hamed, A.N.E.S.; Khalil, H.E.; Kamel, M.S. Phytochemical and pharmacological studies of Citharexylum quadrangulare Jacq. Leaves. J. Med. Plants Res. 2016, 10, 232-241.

36. Balázs, B.; Toth, G.; Duddeck, H.; Soliman, H.S. Iridoid and lignan glycosides from Citharexylum spinosum L. Nat. Prod. Res. 2006, 20, 201-205.

37. Barizão, E.O.; Visentainer, J.V.; Almeida, V.C.; Ribeiro, D.; Chisté, R.C.; Fernandes, E. Citharexylum solanaceum fruit extracts: Profiles of phenolic compounds and carotenoids and their relation with ROS and RNS scavenging capacities. Food Res. Int. 2016, 86, 24-33. [CrossRef] 
38. Saidi, I.; Waffo-Téguo, P.; Ayeb-Zakhama, A.E.L.; Harzallah-Skhiri, F.; Marchal, A.; Ben Jannet, H. Phytochemical study of the trunk bark of Citharexylum spinosum L. growing in Tunisia: Isolation and structure elucidation of iridoid glycosides. Phytochemistry 2018, 146, 47-55. [CrossRef]

39. Mohamed, A.A.; Behiry, S.I.; Younes, H.A.; Ashmawy, N.A.; Salem, M.Z.M.; Márquez-Molina, O.; Barbabosa-Pilego, A. Antibacterial activity of three essential oils and five monoterpenes against Ralstonia solanacearum phylotype II isolated from potato. Microb. Pathogen. 2019, 135, 103604. [CrossRef]

40. Staley, J.T.; Boone, D.R.; Garrity, G.M.; Devos, P.; Fellow, M.G.; Rainey, F.A.; Schlifer, K.H.; Brenner, D.J.; Castenholz, R.W.; Holt, J.G.; et al. Bergey's Manual of Systematic Bacteriology; The Williams and Wilking Company Baltimore Med.: Philadelphia, PA, USA, 2005; Volume 2, p. 469.

41. Thompson, J.D.; Higgins, D.G.; Gibson, T.J. CLUSTAL W: Improving the sensitivity of progressive multiples sequence alignment through sequence weighting, position-specific gap penalties and weight matrix choice. Nucleic Acids Res. 1994, 22, 4673-4680. [CrossRef]

42. Tamura, K.; Peterson, D.; Peterson, N.; Stecher, G.; Nei, M.; Kumar, S. MEGA5: Molecular evolutionary genetics analysis using maximum likelihood, evolutionary distance and maximum parsimony methods. Mol. Biol. Evol. 2011, 28, 2731-2739. [CrossRef]

43. Yaganza, E.S.; Arul, J.; Tweddell, R.J. Effect of pre-storage application of different organic and inorganic salts on stored potato quality. Potato Res. 2004, 46, 167-178. [CrossRef]

44. Sambrook, J.; Fritsch, E.F.; Maniatis, T. Molecular Cloning: A Laboratory Manual, 2nd ed.; Cold Spring Harbor Laboratory: New York, NY, USA, 1989.

45. Salem, M.Z.M.; Behiry, S.I.; EL-Hefny, M. Inhibition of Fusarium culmorum, Penicillium chrysogenum and Rhizoctonia solani by $n$-hexane extracts of three plant species as a wood-treated oil fungicide. J. Appl. Microbiol. 2019, 126, 1683-1699. [CrossRef] [PubMed]

46. NIST/EPA/NIH Mass. Spectral Library (NIST 14) and NIST Mass Spectral Search Program (Version 2.0g) May 2014. Available online: https://www.sisweb.com/software/ms/nist.htm (accessed on 5 March 2019).

47. Salem, M.Z.M.; Mansour, M.M.A.; Elansary, H.O. Evaluation of the effect of inner and outer bark extracts of Sugar Maple (Acer saccharum var. saccharum) in combination with citric acid against the growth of three common molds. J. Wood Chem. Technol. 2019, 39, 136-147. [CrossRef]

48. Abdelsalam, N.R.; Salem, M.Z.M.; Ali, H.M.; Mackled, M.I.; EL-Hefny, M.; Elshikh, M.S.; Hatamleh, A.A. Morphological, biochemical, molecular, and oil toxicity properties of Taxodium trees from different locations. Indu. Crop. Prod. 2019, 139, 111515. [CrossRef]

49. SAS. Users Guide: Statistics (Release 8.02); SAS Institute Inc.: Cary, NC, USA, 2001.

50. Pérombelon, M.C.M.; Kelman, A. Ecology of soft rot Erwinias. Ann. Rev. Phytopathol. 1980, 18, 361-367. [CrossRef]

51. Zhijian, Z.; Shufen, W.; Qi, G.; Xianping, L.; Yunkun, H. Isolation and identification of bacterial soft rot pathogens from potato tubers in Yunnan province. J. Yunnan Agric. Univ. 2000, 15, 499-502.

52. Behiry, S.I.; Ashmawy, N.A.; Abdelkhalek, A.A.; Younes, H.A.; Khaled, A.E.; Hafez, E.E. Compatible- and incompatible-type interactions related to defense genes in potato elucidation by Pectobacterium carotovorum. J. Plant Dis. Prot. 2018, 125, 197-204. [CrossRef]

53. EL-Hefny, M.; Ali, H.M.; Ashmawy, N.A.; Salem, M.Z.M. Chemical Composition and Bioactivity of Salvadora persica Extracts against Some Potato Bacterial Pathogens. BioResources 2017, 12, 1835-1849. [CrossRef]

54. Zayed, A.; Maayouf, M. First record of soft rot on imported potato varieties in Great Libyan Jamahiriya. J. Plant Prot. 1989, 7, 172-173.

55. Choi, J.E.; Man, K.S.; Yu, S.J. Identification of bacteria causing soft rot disease of carrot. Korean J. Plant Pathol. 1989, 5, 349-353.

56. Chung, K.T.; Stevens, S.E.; Lin, W.F., Jr.; Wie, C.I. Growth inhibition of selected food borne bacteria by tannic acid, propyl gallate and related compounds. Lett. Appl. Microbiol. 1993, 17, 29-32. [CrossRef]

57. Hodek, P.; Pavel, T.; Marie, S. Flavonoids potent and versatile biologically active compounds interacting with cytochromes p 450. Chemico-Biol. Interact. 2002, 139, 1-21. [CrossRef]

58. Meddleton, E.; Kandaswami, C.; Theoharides, T.C. The effect of plant flavonoids on mammalian cells: Implications for inflammation, heart disease and cancer. Pharmacol. Rev. 2000, 52, 673-751.

59. Lojkowska, E.; Holubovska, M. The role of polyphenol oxidase and peroxidase in potato tuber resistance to soft rot caused by Erwinia carotovora. J. Phytopathol. 1992, 136, 319-328. [CrossRef] 
60. Hagerman, A.E. Chemistry of Tannin-Protein Complexation. In Chemistry and Significance of Condensed Tannins; Hemingway, R.W., Karchesy, J.J., Branham, S.J., Eds.; Springer: Boston, MA, USA, 1989; pp. 323-333.

61. Liu, I.C.; Hsu, F.L.; Tsai, T.C.; Chan, P.; Liu, J.Y.H.; Thomas, G.N.; Tomlinson, B.; Lo, M.Y.; Lin, J.Y. Antihypertensive effects of tannins isolated from traditional Chinese herbs as non-specific inhibitors of angiotensin converting enzyme. J. Bacteriol. 2003, 73, 1543-1555.

62. Chung, K.T.; Wong, T.Y.; Wei, C.I.; Huang, Y.W.; Lin, W. Tannins and human health: A review. Crit. Rev. Food Sci. Nutr. 1998, 38, 421-464. [CrossRef] [PubMed]

63. Expert, D. With holding and exchanging iron: Interactions between Erwinia spp and their plant hosts. Annu. Rev. Phytopathol. 1999, 37, 307-334. [CrossRef] [PubMed]

64. Hatano, T.; Yoshida, T.; Yoshida, T.; Agata, N.T.; Okuda, T. Effect of interaction of tannins with co-existing substances: Inhibitory effect of tannins and related polyphenols on xanthine oxidase. Chem. Pharm. Bull. 1990, 5, 1224-1229. [CrossRef]

65. Leinmûller, E.; Steingass, H.; Henke, K.H. Tannins in ruminant feed stuffs. Ed. Metzinger. Anim. Res. Dev. 1991, 33, 9-56.

66. Singh, S.; Reddu, S.K.; Sharma, S.K.; Ali, M. New unsaturated fatty acid from roots of Bougainvillea spectabilis Willd. Asian J. Chem. 2009, 21, 4744-4748.

67. Vukovic, N.; Kacaniova, M.; Hleba, L.; Sukdolak, S. Chemical Composition of the Essential oil of Bougainvillea spectabilis from Montenegro. J. Essent. Oil Bear. Plants 2013, 16, 212-215. [CrossRef]

68. Ali, M.S.; Ibrahim, S.A.; Ahmed, F.; Pervez, M.K. Color versus bioactivity in the flowers of Bougainvillea spectabilis (Nyctaginaceae). Nat. Prod. Res. 2005, 19, 1-5. [PubMed]

69. Sudipta, K.M.; Lokesh, P.; Rashmi, W.; Vijay, R.; Ssn, K. Phytochemical screening and in vitro antimicrobial activity of Bougainvillea spectabilis flower extracts. Inter. J. Phytomed. 2012, 4, 375-379.

70. Chowdhury, F.; Pal, S.; Sharmin, T.; Rashid, R.B.; Sikder, M.A.; Kabir, S.; Rahman, M.S.; Rashid, M.A. Bioactivities of artocarpus chaplasha roxb. and Bougainvillea spectabillis willd. Bang. Pharma. J. 2013, 16, $63-68$. [CrossRef]

71. Dhankhar, S.; Sharma, M.; Ruhil, S.; Balhara, M.; Kumar, M.; Chhillar, A.K. Evaluation of antimicrobial and antioxidant activities of Bougainvillea spectabilis. Inter. J. Pharm. Pharma. Sci. 2013, 5, 178-182.

72. Khalifa, T.I.; El-Gendi, O.D.; Ammar, H.A.; El-Naggar, D.M. Iridoid glycosides from Citharexylum quadrangulare. Asian J. Chem. 2012, 14, 197-202.

73. El-Naggar, D.M. Antibilharzial Study of Some Extracts from Citharexylum quadrangular Jacq. Ph.D. Thesis, Al-Azhar University, Cairo, Egypt, 2007.

74. Wei, A.; Shibamoto, T. Antioxidant activities and volatile constituents of various essential oils. J. Agric. Food Chem. 2007, 55, 1737-1742. [CrossRef]

75. Mansour, M.M.A.; Salem, M.Z.M.; Khamis, M.H.; Ali, H.M. Natural durability of Citharexylum spinosum and Morus alba woods against three mold fungi. BioResources 2015, 10, 5330-5344. [CrossRef]

76. Zhang, J.H.; Sun, H.L.; Chen, S.Y.; Zeng, L.; Wang, T.T. Anti-fungal activity, mechanism studies on $\alpha$-Phellandrene and Nonanal against Penicillium cyclopium. Bot. Stud. 2017, 58, 13. [CrossRef]

77. Fernando, W.G.D.; Ramarathnam, R.; Krishnamoorthy, A.S.; Savchuk, S.C. Identification and use of potential bacterial organic antifungal volatiles in biocontrol. Soil Biol. Biochem. 2005, 37, 955-964. [CrossRef]

78. Rodriguez-Burbano, D.; Quijano-Celis, C.; Pino, J. Composition of the essential oil from leaves of Astronium graveolens Jacq grown in Colombia. J. Essent. Oil Res. 2010, 22, 488-489. [CrossRef]

79. Pandey, A.K.; Mohan, M.; Singh, P.; Palni, U.T.; Tripathi, N.N. Chemical composition, antibacterial and antioxidant activity of essential oil of Eupatorium adenophorum Spreng. from Eastern Uttar Pradesh, India. Food Biosci. 2014, 7, 80-87. [CrossRef]

80. Ashmawy, N.A.; Salem, M.Z.M.; EL-Hefny, M.; Abd El-Kareem, M.S.M.; El-Shanhorey, N.A.; Mohamed, A.A.; Salem, A.Z.M. Antibacterial activity of the bioactive molecules identified in three woody plants against some pathogenic bacteria. Microb. Pathogen. 2018, 121, 331-340. [CrossRef]

81. Tenfen, A.; Cechinel-Zanchett, C.C.; Dalmagro, A.P.; Zimath, P.; Boeder, A.M.; Santos, G.M.D.; Campos, A.; Sibert, D.A.; Micke, G.; Vitali, L.; et al. Biological potential of Citharexylum myrianthum Cham. leaves in vitro and phenolic profile by HPLC-ESI-MS/MS. J. Appl. Pharma. Sci. 2018, 8, 74-80.

82. Ashmawy, N.A.; Al Farraj, D.A.; Salem, M.Z.M.; Elshikh, M.S.; Al-Kufaidy, R.; Alshammari, M.k.; Salem, A.Z.M. Potential impacts of Pinus halepensis Miller trees as a source of phytochemical compounds: Antibacterial activity of the cones essential oil and n-butanol extract. Agrofores. Syst. 2018. [CrossRef] 
83. Droby, S.; Eick, A.; Macarisin, D.; Cohen, L.; Rafaela, G.; Stange, R.; McColum, G.; Dudai, N.; Nasser, A.; Wisniewski, M.; et al. Role of citrus volatiles in host recognition, germination and growth of Penicillium digitatum and Penicillium italicum. Postharvest Biol. Technol. 2008, 49, 386-396. [CrossRef]

84. Inouye, S.; Takizawa, T.; Yamaguchi, H. Antibacterial activity of essential oils and their major constituents against respiratory tract pathogens by gaseous contact. J. Antimicrob. Chemother. 2001, 47, 565-573. [CrossRef] [PubMed]

85. Farag, R.S.; Daw, Z.Y.; Hewedi, F.M.; EI-Baroty, G.S.A. Antimicrobial activity of some Egyptian spice essential oils. J. Food Protect. 1989, 52, 665-667. [CrossRef] [PubMed]

86. Smith-Palmer, A.; Stewart, J.; Fyfe, L. Antimicrobial properties of plant essential oils and essences against five important food-borne pathogens. Lett. Appl. Microbiol. 1998, 26, 118-122. [CrossRef]

87. Kubo, A.; Lunde, C.S.; Kubo, I. Antimicrobial activity of the olive oil flavor compounds. J. Agric. Food Chem. 1995, 43, 1629-1633. [CrossRef]

88. Bisignano, G.; Lagana', M.G.; Trombetta, D.; Arena, S.; Nostro, A.; Uccella, N.; Mazzanti, G.; Saija, A. In vitro bacterial activity of some aliphatic aldehydes from Olea europaea L. FEMS Microbiol. Lett. 2001, 198, 9-13. [CrossRef]

89. Mohamed, A.A.; Behiry, S.I.; Ali, H.M.; EL-Hefny, M.; Salem, M.Z.M.; Ashmawy, N.A. Phytochemical Compounds of Branches from P. halepensis Oily Liquid Extract and S. terebinthifolius Essential Oil and Their Potential Antifungal Activity. Processes 2020, 8, 330. [CrossRef]

90. Tassou, C.C.; Nychas, G.J.E. Antimicrobial activity of the essential oil of Mastic gum (Pistacia lentiscus var chia) on gram-positive and gram-negative bacteria in broth and model food systems. Int. Biodeterior. Biodegr. 1995, 36, 411-420. [CrossRef]

91. Mann, C.M.; Cox, S.D.; Markham, J.L. The outer membrane of Pseudomonas aeruginosa NCTC6749 contributes to its tolerance to the essential oil of Melaleuca alternifolia (tea tree oil). Lett. Appl. Microbiol. 2000, 30, $294-297$. [CrossRef] [PubMed]

92. Bajpai, V.K.; Sharma, A.; Baek, K.H. Antibacterial mode of action of Cudrania tricuspidata fruit essential oil, affecting membrane permeability and surface characteristics of food-borne pathogens. Food Control. 2013, 32, 582-590. [CrossRef]

93. Tsuchiya, H. Biphasic effects of acetaldehyde-biogenic amine condensation products on membrane fluidity. J. Pharm. Pharmacol. 2001, 53, 121-127. [CrossRef]

94. Marquis, R.E.; Clock, S.A.; Mota-Meira, M. Fluoride and organic weak acids as modulators of microbial physiology. FEMS Microbiol. Rev. 2003, 26, 493-510. [CrossRef]

95. Helal, G.A.; Sarhan, M.M.; Abu Shahla, A.N.K.; Abou El-Khair, E.K. Effects of Cymbopogon citratus L. essential oil on the growth, lipid content and morphogenesis of Aspergillus niger ML2-strain. J. Basic. Microb. 2006, 46, 456-469. [CrossRef]

96. Helal, G.A.; Sarhan, M.M.; Abu, S.A.N.K.; Abou, E.E.K. Effects of Cymbopogon citratus L. essential oil on the growth, morphogenesis and aflatoxin production of Aspergillus flavus ML2-strain. J. Basic Microb. 2007, 47, 5-15. [CrossRef]

97. Dias, M.I.; Sousa, M.J.; Alves, R.C.; Ferreira, I.C.F.R. Exploring plant tissue culture to improve the production of phenolic compounds: A review. Ind. Crops Prod. 2016, 82, 9-22. [CrossRef]

98. Pereira, D.M.; Valentão, P.; Pereira, J.A.; Andrade, P.B. Phenolics: From chemistry to biology. Molecules 2009, 14, 2202-2211. [CrossRef]

99. Pragasam, S.J.; Murunikkara, V.; Sabina, E.P.; Rasool, M. Ameliorative effect of p-coumaric acid, a common dietary phenol, on adjuvant-induced arthritis in rats. Rheumatol. Int. 2013, 33, 325-334. [CrossRef] [PubMed]

100. Heleno, S.A.; Martins, A.; Queiroz, M.J.R.P.; Ferreira, I.C.F.R. Bioactivity of phenolic acids: Metabolites versus parent compounds: A review. Food Chem. 2015, 173, 501-513. [CrossRef] [PubMed]

101. Pei, K.; Ou, J.; Huang, J.; Ou, S. p-Coumaric acid and its conjugates: Dietary sources, pharmacokinetic properties and biological activities. J. Sci. Food Agric. 2016, 96, 2952-2962. [CrossRef] [PubMed]

102. Yang, W.S.; Jeong, D.; Yi, Y.; Park, J.G.; Seo, H.; Moh, S.H.; Hong, S.; Cho, J.Y. IRAK1/4-targeted anti-inflammatory action of caffeic Acid. Mediat. Inflamm. 2013, 2013, 518183. [CrossRef] [PubMed]

103. Teodoro, G.R.; Ellepola, K.; Seneviratne, C.J.; Koga-Ito, C.Y. Potential use of phenolic acids as anti-candida agents: A review. Front. Microbiol. 2015, 6, 1-11. [CrossRef] [PubMed]

104. Joshi, J.R.; Burdman, S.; Lipsky, A.; Yedidia, I. Effects of plant antimicrobial phenolic compounds on virulence of the genus Pectobacterium. Res. Microbiol. 2015, 166, 535-545. [CrossRef] 
105. Martins, N.; Barros, L.; Henriques, M.; Silva, S.; Ferreira, I.C.F.R. Activity of phenolic compounds from plant origin against Candida species. Ind. Crops Prod. 2015, 74, 648-670. [CrossRef]

106. Parkar, S.G.; Stevenson, D.E.; Skinner, M.A. The potential influence of fruit polyphenols on colonic microflora and human gut health. Int. J. Food Microbiol. 2008, 124, 295-298. [CrossRef]

107. Karunanidhi, A.; Thomas, R.; Van Belkum, A.; Neela, V. In vitro antibacterial and antibiofilm activities of chlorogenic acid against clinical isolates of Stenotrophomonas maltophilia including the Trimethoprim/Sulfamethoxazole resistant strain. BioMed Res. Int. 2013, 2013, 392058. [CrossRef]

108. Jeong, J.M.; Lee, K.I.; Kim, S.M. Simultaneous determination of benzoic Acid, caffeic acid and chlorogenic acid in seeds of Eriobotrya japonica and their antibacterial effect. J. Appl. Biol. Chem. 2014, 57, 89-93.

109. Wang, J.; Lou, J.; Luo, C.; Zhou, L.; Wang, M.; Wang, L. Phenolic compounds from Halimodendron halodendron (Pall.) voss and their antimicrobial and antioxidant activities. Int. J. Mol. Sci. 2012, 13, 11349-11364. [CrossRef] [PubMed]

(C) 2020 by the authors. Licensee MDPI, Basel, Switzerland. This article is an open access article distributed under the terms and conditions of the Creative Commons Attribution (CC BY) license (http://creativecommons.org/licenses/by/4.0/). 